\title{
TAX COMPLIANCE: THEORIES, RESEARCH DEVELOPMENT AND TAX ENFORCEMENT MODELS
}

\begin{tabular}{|c|c|}
\hline \multicolumn{2}{|c|}{$\begin{array}{c}\text { Fauzan Misra } \\
\text { Department of Accounting, Faculty of Economics } \\
\text { Universitas Andalas, Padang } \\
\text { fauzanmisra@eb.unand.ac.id }\end{array}$} \\
\hline INFO ARTIKEL & ABSTRAK/ABSTRACT \\
\hline $\begin{array}{l}\text { Histori Artikel : } \\
\text { Tgl. Masuk : } 12 \text { Juli } 2019 \\
\text { Tgl. Diterima : } 21 \text { Agustus } 2019 \\
\text { Tersedia Online : } 30 \text { September } 2019 \\
\text { Keywords: } \\
\text { Tax Compliance, Theories, } \\
\text { Variables, Tax Enforcement } \\
\text { Models, Social Psychology, } \\
\text { Economic Deterrence, } \\
\text { Paradigm }\end{array}$ & $\begin{array}{l}\text { Tax compliance is still a serious problem in various } \\
\text { countries. This is indicated by the low level of tax } \\
\text { compliance and tax ratio. This paper aims to discuss tax } \\
\text { compliance from three main perspectives, namely theories } \\
\text { about tax compliance, research variables derived from the } \\
\text { theory put forward, and tax compliance enforcement } \\
\text { models. Broadly speaking, this theory is divided into two, } \\
\text { namely the economic-deterrence model and the fiscal and } \\
\text { social psychology model. For a discussion of the research } \\
\text { variables that have been tested before, this article follows } \\
\text { the classification proposed by Devos (2014). Devos divides } \\
\text { these variables into three classifications, namely tax/ moral } \\
\text { ethics variables, equity and fairness variables and } \\
\text { deterrence measures variables. This paper also discusses } \\
\text { tax compliance as a behavioral phenomenon. Next, the } \\
\text { models of tax law enforcement are explained as proposed } \\
\text { by Alm and Torgler (2011) and several other proposed } \\
\text { models. Alm and Torgler classified the models into three } \\
\text { paradigms, that is, traditional deterrence paradigm, services } \\
\text { paradigm, and trust paradigm. These models are proposed } \\
\text { to build a mutually beneficial enforcement model for tax } \\
\text { authorities and taxpayers. }\end{array}$ \\
\hline
\end{tabular}

\section{PENDAHULUAN}

Memahami mengapa seorang wajib pajak patuh atau tidak patuh dan melakukan tindakan penggelapan pajak (tax evasion) masih merupakan hal yang menarik untuk diketahui, baik secara praktis maupun secara intelektual/teoritis/empiris. Besarnya tax gap (selisih antara pajak yang saharusnya terutang dengan pajak yang dibayar) masih sangat besar dan ini terjadi di banyak negara. Hal ini menunjukkan tingkat ketidakpatuhan yang masih tinggi. Banyak faktor yang menyebabkan hal tersebut dan salah satunya adalah dapat disebabkan penerapan self assessment system. Penerapan sistem ini sangat dipengaruhi oleh faktor perilaku wajib pajak karena memberikan kewenangan dan tanggungjawab yang lebih besar kepada mereka.

$\mathrm{Di}$ Indonesia, Kenyataan menunjukkan bahwa tingkat kepatuhan wajib pajak untuk melaporkan pajaknya masih tergolong rendah. Hal ini dinyatakan oleh Martowardojo (2012) bahwa orang pribadi yang menyerahkan SPT-nya pada tahun 2011 hanya 8,5 juta wajib pajak padahal penduduk yang aktif bekerja ada 110 juta orang (Basri, dkk; 
2012). Angka tersebut berarti rasio SPT terhadap kelompok pekerja aktif hanya 7,7 persen. Kemudian, diluncurkannya program amnesti pajak pada tahun 2016-2017 melalui UU No.11 tahun 2016 tentang Pengampunan Pajak mengindikasikan hal yang sama. Kemudian sebagai perbandingan di Amerika Serikat tax gap mencapai 312-316 Miliar Dolar per tahun (15,2\%-16,6\%) untuk tahun 2005. Angka persentase ini belum menunjukkan keberhasilan dari program yang diluncurkan tahun 1994 untuk meningkatkan tingkat kepatuhan pajak dari $82,3 \%$ menjadi $90 \%$ pada tahun 2001 (Christensen dan Hite, 1997). Bahkan, pada tahun 2001, berdasarkan analisis National Research Program, The U.S Department of Treasury (2006), senjangan kurang bayar mencapai 345 miliar dolar atau sekitar 16,3\% dari kewajiban pajak di Amerika Serikat (Slemrod, 2007). Hal yang sama juga dihadapi oleh pemerintah Australia, level penggelapan pajak diperkirakan mencapai 10 miliar dolar australia atau 1,2\% dari level GDP tahun 2002-2003 (Devos, 2014).

Kemudian, kalau realisasi penerimaan dibandingkan dengan Produk Domestik Bruto (PDB) atau yang lebih populer disebut dengan Tax Ratio, angka persentase tax ratio Indonesia juga masih rendah. Selama tahun 1989-2010 seperti yang diungkapkan oleh Arisanti (2010), tax ratio Indonesia hanya naik sebesar $5,11 \%$ dari $8,19 \%$ tahun 1989 menjadi $13,30 \%$ pada tahun 2010. Masalah ini semakin mendapatkan tantangan dengan tingginya perhatian masyarakat terhadap kasus-kasus perpajakan yang marak beberapa tahun belakangan ini.

Beberapa penelitian sebelumnya telah menguji satu atau kombinasi variabel akuntabilitas, probalilitas audit/risiko terdeteksi, diseminasi informasi pajak, komunikasi pajak antar wajib pajak, kerahasiaan, persepsi terhadap layanan pemerintah, medernisasi sistem perpajakan dan keefektifan sistem perpajakan, keadilan pajak/tax fairness, efektivitas pinalti/denda untuk mengetahui

kepatuhan/ketidakpatuhan wajib pajak. Penelitian tersebut antara lain (Devos 2005; Dubin 2007; Slemrod 2007, Utami, Andi dan Soerono 2012; Fasmi dan Misra, 2012; Handayani, Faturokhman dan Pratiwi 2012:; Pangestu dan Rusmana, 2012)., estimasi pajak terutang dan standar etis yang dimiliki oleh wajib Pajak (Feltham dan Paquette, 2002; Ghost dan Crain, 1996; Alm, Jackson dan Mckee, 2006 dan Asnawi, 2007). Penelitian lain seperti Basri, dkk (2012) memasukkan variabel regiliusitas sebagai salah satu variabel independennya dalam mengukur kepatuhan wajib pajak.

Paper ini memfokuskan kepada pembahasan mengenai teori-teori yang digunakan dalam studi-studi kepatuhan pajak, variabel-variabel yang diteliti berdasarkan teori yang dikemukan serta model-model penegakan kepatuhan pajak yang diusulkan berbagai peneliti sebelumnya. Tulisan ini diharapkan memberikan beberapa kontribusi. Pertama, diharapkan berkontribusi dalam pengembangan model penelitian berbasis teori yang baik. Kedua, memberikan arahan praktis dalam pengembangan model penegakan hukum pajak di Indonesia.

Paper ini akan disajikan sebagai berikut, setelah bagian pendahuluan, pada bagian II dibahas definisi kepatuhan pajak dan kriteria wajib pajak patuh, lalu dilanjutkan dengan penjelasan mengenai kepatuhan pajak sebagai salah satu fenomena 
keperilakuan, kemudian dibahas mengenai teori-teori yang menjelaskan tentang kepatuhan pajak pada bagian IV. Secara garis besar, teori ini terbagi menjadi dua yaitu model economicdeterrence dan model psikologi fiskal dan sosial. Pembahasan berikutnya dilanjutkan dengan diskusi mengenai variabel-variabel kepatuhan pajak yang telah banyak diuji oleh peneliti sebelumnya beserta dengan perkembangan risetnya selama beberapa dekade pada bagian $\mathrm{V}$. Untuk pembahasan variabel-variabel ini, artikel ini mengikuti klasifikasi yang diajukan oleh Devos (2014). Devos membagi variabel-variabel tersebut ke dalam tiga klasifikasi yaitu variabel etika/moral pajak (tax morale/ethics variables), variabel keadilan pajak (equity dan fairness variables) dan variabel ukuran-ukuran pencegahan (deterrence measures variables). Bahasan berikutnya pada bagian VI adalah mengenai usulan model penegakan kepatuhan pajak dengan mempertimbangan semua variabelvariabel yang telah diuji sebelumnya. Bagian VII adalah kesimpulan yang merupakan bagian terakhir dari artikel ini.

\section{Definisi Kepatuhan Pajak dan Kriteria Wajib Pajak Patuh}

Karena fokus artikel ini adalah mengenai kepatuhan pajak, maka definisi kepatuhan pajak sangat penting untuk dipertimbangkan dan dipahami. Kepatuhan berasal dari kata patuh yang diartikan sebagai taat atau patuh terhadap aturan-aturan yang diterapkan. Dengan demikian, kepatuhan pajak dapat diartikan sebagai kepatuhan wajib pajak untuk melaksanakan semua kewajiban perpajakannya sesuai dengan peraturan perpajakan.
Dari pengertian di atas dapat dikatakan bahwa jika wajib pajak gagal dalam memenuhi kewajiban pajaknya, baik disengaja maupun tidak, maka dapat dikatakan sebagai ketidakpatuhan. Ketidakpatuhan dapat dilakukan dengan berbagai cara salah satunya adalah dengan sengaja mengurangi jumlah pajak terutangnya/kewajiban pajak (Hayman, 1993). Cara ini dapat dilakukan dengan memanipulasi datadata dan laporan keuangan yang akan digunakan untuk tujuan pajak. Atas dasar inilah kepatuhan/ketidakpatuhan pajak dapat dipengaruhi oleh faktor internal individu (psikologis) dan faktor eksternal individu atau dalam beberapa riset seperti dikemukan oleh Asnawi (2007) sebagai faktor ekonomi dan non-ekonomi.

Definisi yang lebih komprehensif diberikan oleh Roth et al. (1989). Menurut mereka, kepatuhan pajak adalah kepatuhan terhadap persyaratan pelaporan, yang bermakna bahwa, wajib pajak menyampaikan semua surat pemberitahuan pajak yang disyaratkan secara tepat waktu dan laporan tersebut berisi pelaporan kewajiban pajak secara akurat sesuai dengan UU dan ketentuan perpajakan berlaku pada saat pelaporan. Definisi ini sejalan dengan definisi yang dikemukan oleh Nurmantu (2003). Menurut Nurmantu (2003) mengartikan kepatuhan perpajakan didefinisikan sebagai suatu keadaan dimana wajib pajak memenuhi semua kewajiban perpajakan dan melaksanakan hak perpajakannya. Terdapat dua macam kepatuhan, yaitu kepatuhan formal dan kepatuhan material. Kepatuhan formal adalah suatu keadaan dimana wajib pajak memenuhi kewajiban perpajakan secara formal sesuai dengan ketentuan dalam undang-undang 
perpajakan. Misalnya ketentuan batas waktu penyampaian Surat Pemberitahuan. Apabila wajib pajak telah melaporkan Surat Pemberitahuan Pajak Penghasilan (SPT PPh) Tahunan sebelum batas waktu maka dapat dikatakan bahwa wajib pajak telah memenuhi ketentuan formal, akan tetapi isinya belum tentu memenuhi ketentuan material. Kepatuhan material yaitu suatu keadaan dimana wajib pajak secara substantif memenuhi semua ketentuan material perpajakan, yakni sesuai isi dan jiwa undang-undang perpajakan. Wajib pajak yang memenuhi kepatuhan material adalah wajib pajak yang mengisi dengan jujur, lengkap, dan benar Surat Pemberitahuan (SPT) sesuai ketentuan dan menyampaikannya ke KPP sebelum batas waktu berakhir.

\subsection{Kriteria Wajib Pajak Patuh}

Definisi yang dikemukan oleh Roth et al. (1989), Nurmantu (2003) dan Eliyani dalam Jatmiko (2006) di atas, mengasumsikan bahwa agar patuh dengan hukum pajak, seseorang harus mendeklarasikan/menyampaikan jumlah pendapatan secara benar, mengklaim secara benar biaya-biaya yang dapat dijadikan sebagai pengurang pajak terutang (deductible expenses) dan berikutnya, membayar pajak terutang dengan jumlah yang benar pada waktu yang ditentukan.

Sementara itu, secara legal formal, kriteria pengusaha pajak patuh menurut Keputusan Menteri Keuangan No.235/KMK.03/2003 adalah:

1. Tepat waktu dalam menyampaikan SPT untuk semua jenis pajak dalam dua tahun terakhir.

2. Tidak mempunyai tunggakan pajak atau untuk semua jenis pajak, kecuali telah memperoleh izin untuk mengangsur atau menunda pembayaran pajak.

3. Tidak pernah dijatuhi hukuman karena melakukan tindak pidana di bagian perpajakan dalam jangka waktu 10 tahun terakhir.

4. Dalam 2 tahun terakhir menyelenggarakan pembukuan dan dalam hal terhadap wajib pajak pernah dilakukan pemeriksaan, koreksi pada pemeriksaan yang terakhir untuk masing-masing jenis pajak yang terutang paling banyak $5 \%$.

5. Wajib pajak yang laporan keuangan untuk 2 tahun terakhir diaudit oleh akuntan publik dengan pendapat wajar tanpa pengecualian, atau pendapat dengan pengecualian sepanjang tidak memengaruhi laba fiskal."

\section{Kepatuhan Pajak sebagai}

\section{Fenomena Keperilakuan}

Asnawi (2007) mengemukakan permasalahan kepatuhan pajak dapat dilihat dari dua pendekatan yaitu pendekatan ekonomi (seperti suplai tenaga kerja, pilihan lapangan kerja, pinalti/sanksi/denda, tarif pajak, pelayanan pemerintah, pendapatan, strategi audit oleh fiskus, perceived probability audit, dll) dan pendekatan non-ekonomi yang dalam banyak literatur menggambarkan perilaku psikologi wajib pajak (seperti etika, norma sosial, keadilan, harapan, akuntabilitas, dan lain-lain). Banyak penelitian terdahulu mengkombinasikan faktor ekonomi dan non-ekonomi tersebut dalam menjelaskan tentang kepatuhan wajib pajak.

Dari perspektif non-ekonomik, terdapat Hasseldine et al. (2007) yang 
menguji efektivitas komunikasi persuasif dan Blumental, Christian dan Slemrod (2001) yang menguji dampak panggilan normatif (normatif appeal) terhadap kepatuhan pajak. Kemudian, Kaplan, Newberry dan Recker (1997) menguji perbandingan efektivitas antara penalaran moral dan komunikasi edukasional terhadap kepatuhan pajak. Worsham Jr. (2006) menguji perilaku fiskus sebagai bentuk persepsi keadilan oleh wajib pajak. Dari perspektif ekonomik sangat banyak sekali penelitian tentang pengaruh probabilitas audit, strategi audit, tarif dan sanksi/pinalti (seperti Ghost dan Crain, 1996; Feltham dan Paquette, 2002; Asnawi, 2009; Milliron dan Toy, 1988 dan Violette, 1989). Selain itu, beberapa penelitian lainnya seperti Braitwaite (2003a dan 2009) menonjolkan terdapatnya faktor motivasi dalam keputusan kepatuhan pajak. Mereka membagi motivasi wajib pajak untuk patuh menjadi motif "deterrence" dan "defiance". Penelitian pajak yang menguji dampak pembingkaian (framing effect) terhadap keputusan kepatuhan pajak seperti dilakukan oleh Schepanski dan Kelsey (1990), White, Harrison dan Harrel (1993) dan Fatemi, Hasseldine dan Hite (2008) memberikan bukti tambahan bahwa penelitian kepatuhan pajak telah dipelajari dari berbagai perspektif.

Berbagai penelitian tersebut memberikan keyakinan yang cukup bahwa dari berbagai perspektif tersebut, jika dikerucutkan lagi maka dapat dikatakan bahwa kepatuhan pajak merupakan sebuah fenomena keperilakuan. Secara lebih jelas, jika kita menelusuri kembali ke level paling elementer, penelitian Alligham dan Sandmo (1972) yang bertumpu pada pendekatan economics-of-crime, maka kita akan menemukan bahwa wajib pajak dinilai menghadapi perjudian diantara kondisi (states of the world): pada satu sisi individu/wajib pajak akan melaporkan pendapatan dan membayar pajak sedangkan pada sisi lain individu/wajib pajak tidak melaporkan pendapatan dan karenanya melakukan penggelapan pajak. Individu-individu tersebut membandingkan utilitas harapan mereka dari pelaporan (opsi penghematan) dengan utilitas ekspektasian dari penggelapan (opsi berisiko).

Secara lebih rinci, di dalam Alm et al. (2010) dijelaskan, misalkan seorang individu mempunyai pendapatan $\boldsymbol{I}$, dan harus memilih untuk melaporkan kepada otoritas pajak. Pendapatan yang dilaporkan $\boldsymbol{R}$ akan dikenakan pajak pada tarif $\boldsymbol{t}$. Pendapatan yang tidak dilaporkan tidak akan dikenakan pajak, namun, individu tersebut mungkin akan diperiksa dengan probabilitas tertentu dan diketahui $\boldsymbol{p}$, pada titik semua pendapatan yang tidak dilaporkan ditemukan dan denda $\boldsymbol{f}$ akan dikenakan atas setiap rupiah (dolar) yang tidak dibayarkan pajaknya. Pendapatan individu Ic jika underreporting ditemukan adalah:

$$
\mathrm{IC}=\mathrm{I}-\mathrm{tR}-\mathrm{ft}(\mathrm{I}-\mathrm{R})
$$

Sementara jika underreporting tidak ditemukan, maka pendapatan $\mathbf{I}_{\mathbf{N}}$ adalah:

$$
I_{N}=I-t R
$$

Individu akan memilih $R$ untuk memaksimalkan utilitas ekspektasiannya EU (I) dari perjudian penggelapan, atau: 
$E U(I)=p U\left(I_{C}\right)+(1-p) U\left(I_{N}\right)$.

(3)

dalam hal ini $U(\mathrm{I})$ diasumsikan sebagai fungsi hanya pendapatan (function only of income) dan E adalah operator ekspektasi.

Penjelasan tentang utilitas ekspektasian di atas sebenarnya terlalu menyederhanakan fenomena perpajakan yang lebih kompleks. Kondisi atau setting individual sebenarnya jauh lebih kompleks dan kompleksitas ini mempengaruhi perilaku wajib pajak dalam pemenuhan kewajiban perpajakannya.

Alm et al. (2010) memodifikasi model penggelapan pajak tradisional dengan menyatakan bahwa nilai utilitas ekspekstasian antara wajib pajak yang menyampaikan SPT akan berbeda dengan wajib pajak yang tidak menyampaikan SPT. Keduanya menghadapi kondisi yang berbeda serta risiko yang berbeda juga. Wajib pajak yang tidak menyampaikan SPT akan mempunyai utilitas ekspektasian sebesar $\left.\left(1+f^{\prime}\right) t l\right)$

$$
E U(I)=\left(1-p^{\prime}\right) U(I)-p^{\prime} U(I-1
$$

Dalam hal ini p' adalah probabilitas wajib pajak yang tidak menyampaikan SPT untuk diperiksa, I, adalah pendapatan, $f$ adalah denda jika terdeteksi tidak menyampaikan SPT serta $t$ adalah tarif pajak. Wajib pajak yang menyampaikan SPT (dan tentunya melaporkan pendapatan) akan mempunyai nilai utilitas ekspektasian setelah memperhitungkan pendapatan, pengurangan dan kredit pajak yang diijinkan serta probabilitas mereka akan diperiksa dan dikenai sanksi. Dengan penyediaan informasi oleh administrator pajak, maka ketidakpastian akan berkurang khususnya terkait dengan pengurangan dan kredit pajak yang pada akhirnya dapat mengurangi biaya penyeselaian SPT. Dengan adanya informasi pengurangan pajak yang diberikan, pendapatan Ic mereka adalah sebesar

$$
I C=I-t(R-D)-f t(I-(R-D))-C
$$

Sedangkan pendapatan $I_{N}$ menjadi

$$
I_{N}=I-t(R-D)-C-V
$$

(6)

Sehingga utilitas ekspektasian mereka menjadi:

$$
E U(I)=p U\left(I_{C}\right)+(1-p) U\left(I_{N}\right)
$$

dalam hal ini $\mathrm{y}$ adalah biaya fisik yaitu biaya berkaitan dengan aktivitas penipuan (cheating) dalam menyampaikan SPT dan D adalah pengurangan yang diperbolehkan. Notasi lainnya sama dengan penjelasan sebelumnya.

Wajib pajak sekarang menghadapi hitung-hitungan yang lebih rumit dan kompleks. Wajib pajak terlebih dahulu akan memutuskan apakah akan menyampaikan SPT atau tidak dengan membandingkan utilitas yang mereka peroleh dari tidak menyampaikan SPT (persamaan 4) dengan utilitas ekspektasian jika mereka menyampaikan SPT (persamaan 7) dengan menggunakan definisi modifikasian Ic dan $I_{N}$ pada persamaa (5) dan (6). Jika wajib pajak memutuskan untuk menyampaikan SPT maka ia akan memilih jumlah optimal penghasilan yang dilaporkan 
dan pengurangan yang diperbolehkan, dari maksimisasi persamaan (5) ke persamaan (7).

\section{Teori Kepatuhan Pajak}

\subsection{Model Economic Deterrence}

Selama tahun 1980-an struktur penelitian mengenai penggelapan pajak dan ketidakpatuhan berkembang mengikuti perspektif politik di Amerika Serikat dengan perhatian utama pada masalah "tax gap". Pada awalnya, literatur-literatur pajak yang dikembangkan dari Amerika Serikat punya fokus yang kuat terhadap teoriteori ekonomik dan teori utilitas. Teori Utilitas, yang dikembangkan oleh Allingham dan Sandmo (1972) mengasumsikan wajib pajak sebagai "utility maximizer" dalam keputusan pelaporan dan kepatuhan pajak, dalam hal ini penggelapan pajak dianggap bernilai jika keuntungan finansial yang diperoleh melebihi biaya-biaya finansial yang timbul. Pendekatan ini kemudian dikenal dengan pendekatan deterrence atau model economics-ofcrime. Model ini telah menginspirasi berbagai pengujian empiris seperti Alm (1991), Cowell (1990), Elffers (1991), Andreoni et al. (1998), dan Slemrod (2007). Menurut model ini, deterrence
dapat dicapai melalui sejumlah
pendekatan, punitive dan persuasif.
Maksudnya, deterrence dapat mengambil berbagai bentuk seperti peningkatan probabilitas pemeriksaan dan deteksi, meningkatkan tarif pajak dan pengenaan pinalti berupa denda dan sanksi. Bentuk lain adalah pendidikan yang lebih baik, meningkatkan iklan/publikasi dan insentif. Model ini mengasumsikan bahwa wajib pajak adalah utility maximizer dan akan memilih untuk melakukan penggelapan pajak jika keuntungan yang diperoleh melebihi biaya yang dikeluarkan. Sederhananya dapat dikatakan bahwa keputusan kepatuhan pajak diambil berdasarkan perhitungan "cost-benefit" wajib pajak. Beberapa peneliti mengajukan argumen bahwa individu diekpektasikan akan menimbang "manfaat yang belum pasti dari penggelapan yang berhasil dengan risiko terdeteksi akibat kecurangan yang dilakukan".

Model deterrence telah sangat umum digunakan untuk menjelaskan dan menguji penggelapan dan kepatuhan pajak dari perspektif teoretis. Faktor-faktor yang telah diuji dalam model deterrence ini antara lain kompleksitas sistem perpajakan, level pelayanan informasi pendapatan, pelaporan informasi dan pemotongan pajak oleh pihak ketiga (withholding), tanggung-jawab dan pinalti penyaji laporan pajak, probabilitas mendapatkan pemeriksaan pajak, tarif pajak progresif, dan pinalti untuk ketidakpatuhan.

\subsection{Pendekatan Psikologi}

\section{Fiskal/Sosial}

Meskipun temuan mereka mengkonfirmasi mekanisma model pencegahan (deterrence model) tersebut, namun masih diperlukan pengujian-pengujian yang mempertimbangkan aspek lain dari kepatuhan (atau ketidak-patuhan) pajak. Fakta ini kemudian memotivasi eksplorasi lebih lanjut dimensi-dimensi kepatuhan pajak seperti moral pajak, etika dan norma (seperti Torgler, 2002), norma masyarakat (Slemrod, 1998), panggilan moral (Schward dan Orleans, 1967; Blumenthal et al., 2001 dan Torgler, 2004).

Panggilan untuk menggali dimensi lain ini sejalan dengan perkembangan terbaru dari penelitianpenelitian mengenai penggelapan dan 
ketidakpatuhan pajak. Studi-studi kepatuhan pajak kemudian banyak didasarkan kepada teori-teori psikologi fiskal dan sosial. Studi dalam ranah ini berargumen bahwa manusia memainkan peranan penting dalam keputusan kepatuhan pajak individual. Model psikologi fiskal/sosial fokus kepada variabel-variabel psikologis seperti nilai moral dan persepsi keadilan dalam sistem perpajakan dan otoritas pajak. Model psikologi fiskal menggabungkan aspek dari model economic-deterrence dan model psikologi sosial.

Berlawanan dengan model pertama yang mengasumsikan wajib pajak sebagai utility maximizer, model psikologi fiskal tidak secara sederhana mengatakan demikian. Pendekatan ini mengasumsikan bahwa individu mengakui peran dari hal-hal yang membentuk sikap dan keyakinan (belief) yang beriteksi satu sama lain dalam merespon norma sosial. Model psikologi fiskal secara induktif menguji sikap dan keyakinan wajib pajak untuk memahami dan memprediksi perilaku wajib pajak. Studi-studi berdasarkan model ini lebih menekankan kepada penjelasan dan pengujian mengenai faktor-faktor manusia yang mempengaruhi sikap dan perilaku kepatuhan wajib pajak.

\section{Variabel-Variabel Kepatuhan}

\section{Pajak dan Perkembangan}

\section{Penelitiannya}

Berdasarkan penjelasan mengenai teori-teori kepatuhan pajak, variabelvariabel yang banyak terkait dengan penggelapan dan kepatuhan pajak diteliti dapat diklasifikan menjadi 3 kelompok. Ketiga klasifikasi ini berdasarkan rerangka yang dikemukan oleh Devos (2014). Ketiga variabel tersebut adalah variabelvariabel etika/moral pajak, variabel- variabel keadilan dan variabel-variabel ukuran deterrence. Kelompok pertama dan kedua diturunkan dari teori psikologi fiskal/sosial sementara kelompok terakhir diturunkan dari model economic-deterrence.

\subsection{Moral/Etika Pajak}

Menurut Reckers et al. (1994), nilai moral berhubungan dengan nilai dan norma yang diwarisi oleh seseorang. Reckers et al. juga mendefinisikan nilai etis sebagai sistem normatif dari aturan perbuatan untuk menyediakan panduan dalam setting sosial dan inperpersonal. Secara lebih spesifik, Song dan Yarborough (1978) dikutip dari Devos (2014) mendefinisikan etika wajib pajak sebagai norma keperilakuan yang mengatur warga negara sebagai wajib sebagai wajib pajak dalam hubungan mereka dengan pemerintah. Beberapa peneliti mengajukan beberapa proksi untuk variabel ini antara lain etika pajak (Reckers et al., 1994), nilai etis (Antonides dan Robben, 1995), perasaan bersalah (Thurman, 1991), nilai moral (Schwartz dan Orleans, 1967 dan Torgler dan Murphy, 2004). Menurut Devos (2014), meskipun terdapat variansi dalam istilah yang digunakan, moral pajak secara umum dapat dipahami sebagai prinsip-prinsip moral atau nilai-nilai yang dipegang oleh individu tentang apakah akan membayar atau tidak membayar pajak mereka.

Beberapa riset mengenai etika atau moral pajak antara lain yang dilakukan oleh peneliti-peneliti yang mengajukan proksi atas variabel etika/moral pajak. Studi awal dilakukan oleh Schwartz dan Orleans, 1967 yang menguji moral pajak dan membandingkan antara ancaman sanksi dan panggilan untuk sadar (appeal to conscience) sebagai determinan kepatuhan legal. Song dan 
Yarborough (1978) dengan menggunakan pendekatan survey menginvestigasi pengaruh etika pajak terhadap kepatuhan sukarela. Pada tahun 1980-an, penelitian Kaplan dan Reckers (1985) memberikan pengaruh yang cukup besar dalam penelitian etika pajak. Temuan studi mereka mengindikasikan bahwa terdapat hubungan ukuran umum nilai moral dengan kepatuhan pajak. Pada tahun 2000-an antara lain terdapat penelitian dari Trivedi (2005) yang memfokuskan kepada dimensi penalaran moral dalam hubungannya dengan kepatuhan pajak dan Torgler (2003) menganalisis faktor-faktor yang membentuk moral pajak. Berbeda dengan sebagian riset lain, ia menempatkan moral pajak sebagai variabel dependen.

\subsection{Keadilan (Equity and Fairness)}

Berdasarkan reviu terhadap model psikologi fiskal dan sosial, terbukti bahwa keadilan pajak merupakan salah satu faktor utama yang menentukan kepatuhan pajak. Keadilan (equity dan fairness) mengacu kepada pandangan keadilan keseluruhan wajib pajak terhadap sistem perpajakan. Secara spesifik, terdapat 3 dimensi keadilan yang diinvestigasi dalam banyak penelitian yaitu keadilan vertikal, keadilan horinzontal dan keadilan dalam pertukaran dengan pemerintah. Devos (2014) memberikan definsisi atas ketiga bentuk dimensi keadilan ini. Keadilan vertikal mengacu kepada persepsi bahwa sistem pajak memperlakukan setiap orang secara sama relatif terhadap level pendapatan mereka. Keadilan horizontal adalah persepsi bahwa semua wajib pajak yang mempunyai pengahsilan yang sama harus diperlakukan secara sama dan bahwa beban pajak dibagi kepada semua wajib pajak secara adil dalam situasi ekonomis yang serupa. Sedangkan keadilan pertukaran dengan pemerintah meengacu kepada keadilan dalam pertukaran barang dan jasa dari pemerintah sebagai kembalian dari pajak yang dibayar. Terdapat juga penelitian yang menggunakan 3 dimensi keadilan yang umum dikenal yaitu keadilan distributif, prosedural dan interaktif.

Beberapa penelitian mengenai keadilan pajak ini antara lain Thibaut et al., (1974) yang mempertimbangkan konsep keadilan dan komitmen terhadap sistem pajak. Pada perioda 1980-an terdapat Spicer dan Becker (1980) yang menguji hubungan antara ketidakadilan fiskal persepsian dan penggelapan pajak. Pada tahun 1990an terdapat studi yang menguji keadilan dari 3 dimensi seperti dijelaskan di atas oleh Collins et al., (1992). Mereka menemukan terdapat hubungan signifikan antara ketidakadilan persepsian dengan keputusan kepatuhan pajak pada beberapa subgrup dalam model kontinjensi mereka. Perbedaan antar sub-grup ini diduga karena dipengaruhi oleh kontribusi secara tidak langsung dari niat (intensi) wajib pajak terhadap kepatuhan pajak. Tahun 2000-an terdapat Kirchler et al., (2006) yang menemukan bahwa keadilan prosedural berpengaruh terhadap niat kepatuhan pajak.

\subsection{Ukuran-Ukuran} Pencegahan (Deterrence Measures)

Variabel-variabel kategori ini diturunkan dari model economicdeterrence. Reviu terhadap literatur kepatuhan pajak menunjukkan bahwa banyak studi yang telah menguji hubungan antara persepsi wajib pajak terhadap beragam mekanisma deterrence dan kepatuhan pajak. Temuan untuk riset-riset dalam 
klasifikasi ini masih menghasilan temuan yang bertentangan satu sama lain, sebagai contoh mengenai pengaruh sanksi terhadap kepatuhan pajak. Devos (2014) membagi 2 tujuan dari deterrence yaitu specifik deterrence dan general deterrence. Spesifik deterrence yang merupakan bentuk penerapan sanksi kriminal bertujuan untuk menghindari pelaku kejahatan untuk mengulangi perbuatannya sedangkan general deterrence bertujuan untuk mencegah pelanggar potensial.

Sudah sangat banyak penelitian dalam area ini, setidaknya terdapat 13 riset yang cukup berpengaruh pada masing-masing dekade seperti telah dijelaskan sebelumnya pada tabel 1 . Sebagai tambahan atas reviu pada tabel 1, yang terbaru telah dilakukan beberapa riset yang menunjukkan bahwa aliran riset berdasarkan model ini masih terus berkembang meskipun kelihatannya belakangan penelitianpenelitian kepatuhan pajak lebih banyak menggukan model psikologi fiskal/sosial. Beberapa riset terbaru antara lain Kirchler et al., (2007) yang memperkenalkan istilah "slippery slope framework" dalam menjelaskan pengaruh kekuasaan (power) dari dan kepercayaan (trust) kepada otoritas pajak dan interaksi keduanya terhadap kepatuhan pajak. Juga terdapat Hasseldine et al., (2007) yang menekankan kepada peran komunikasi persuasif (secara tertulis) kepada wajib pajak terhadap perilaku kepatuhan aktual wajib pajak. Temuan riset ini secara umum menunjukkan adanya pengaruh komunikasi persuasif terhadap kepatuhan wajib pajak.

Menentukan strategi reinforcement pajak yang paling efektif dalam memperoleh kepatuhan sukarela dalam jangka panjang adalah tantangan bagi semua fiskus di seluruh dunia (Murphy, 2008). Debat yang sudah lama terjadi antara lain antara pendapat yang mengatakan bahwa cara yang paling efektif adalah dengan pengenaan sanksi dan pinalti yang keras sementara yang lain percaya bahwa persuasi secara gentle dan ramah serta kerjasama yang baik akan lebih efektif (Braithwaite, 1992). Kedua pendekatan ini menjelaskan pendekatan dengan model deterrence dan pendekatan akomodatif (psikologis).

Alm dan Torgler (2011) menyatakan terdapat 3 paradigma administratif yang mempengaruhi kepatuhan pajak. Paradigma pertama adalah paradigma "enforcement" yang berasal dari pendekatan economics-ofcrime. Paradigma ini menekankan pada detection dan punishment. Upaya peningkatan kepatuhan pajak tradisional melalui "enforcement" yang memandang dan memperlakukan wajib pajak sebagai pelaku kriminal potensial menurut pendekatan economics-of-crime dinilai sebagai paradigma yang tidak lengkap (Alm, et al. 2010). Paradigma "enforcement" ini menuyiratkan bahwa diperlukan frekuensi audit yang tinggi dan pengenaan pinalti untuk meningkatkan kepatuhan pajak (Allingham dan Sandmo, 1972) Selain dibutuhkan biaya yang tidak sedikit untuk melakukan pemeriksaan pajak (Hasseldine et al. 2007), intensitasnya juga cenderung menurun (seperti dinyatakan dalam Alm, Jackson dan Mckee, 2006).

Paradigma kedua, pelayanan (services), mengakui bahwa selain peran "enforcement", juga perlu menekankan pada peran administrasi perpajakan sebagai fasilitator dan penyedia layanan kepada masyarakatwajib pajak. Paradigma ini 
menjelaskan tentang peran pemerintah untuk memberikan pelayanan, termasuk berkaitan dengan kepatuhan pajak. Salah satu yang mendukung paradigma pelayanan ini antara lain adalah Alm dan MartinezVazques (2003). Paradigma pelayanan mengakui bahwa selain peran "enforcement", juga perlu menekankan pada peran administrasi perpajakan sebagai fasilitator dan penyedia layanan kepada masyarakatwajib pajak. Bentuk aplikasi paradigma ini adalah penyediaan dan bantuan informasi yang lebih bersahabat, lunak dan membantu serta komunikasi yang persuasif dengan wajib pajak (Doyle et al., 2009; Hasseldine at al., 2007 dan Chung dan Trivedi, 2003).

Ketiga, paradigma "trust" yang diperkenalkan oleh Kirchler et al. (2008). Kedua paradigma perluasan ini berangkat dari seminal work Lewis (1982) tentang psikologi perpajakan. Bahkan, beberapa reformasi perpajakan di berbagai negara belakangan ini telah menganut paradigma pelayanan ini, termasuk Indonesia. Alm et al. (2010) mengatakan bahwa paradigma enforcement harus ditopang dengan paradigma lainnya untuk meningkatkan keefektifan upaya peningkatan kepatuhan pajak.

Kedua paradigma perluasan
dari pendekatan tradisional enforcement ini berangkat dari seminal work Lewis (1982) tentang psikologi perpajakan. Bahkan, beberapa reformasi perpajakan di berbagai negara belakangan ini telah menganut paradigma pelayanan ini, termasuk Indonesia. Braithwaite (2003) menyatakan bahwa agensi pajak telah lebih perhatian dengan pelayanan mereka dalam dekade terakhir. Alm et al. (2010) mengatakan bahwa paradigma enforcement harus ditopang dengan paradigma lainnya untuk meningkatkan keefektifan upaya peningkatan kepatuhan pajak.

\subsection{Evaluasi terhadap Model Tradisional dan Pengembangan Paradigma Pelayanan dan Kepercayaan}

Model ekonomi penggelapan pajak penghasilan (Allingham dan Sandmo, 1972) berdasarkan kepada pendekatan the economics-of-crime yang dipelopori oleh Becker (1968) dianggap tidak lengkap. Model ini fokus pada pelaku pelaporan pajak dari wajib pajak, dan mengabaikan bentuk lain dari penggelapan pajak seperti tidak membayar, pelaporan pengurangan (deduction) yang melebihi kewajaran dan tidak melaporkan SPT. Model ekonomi atau paradigma enforcement ini membutuhkan pemeriksaan pajak dengan frekuensi memadai, namun, audit bukan tanpa biaya (Hasseldine et al., 2007) dan kecenderungan umum menunjukkan terjadinya penurunan tingkat audit (Alm, Jackson dan Mckee, 2009) sehingga paradigma ini perlu ditopang dengan upaya yang lain. Oleh karena itu, insentif untuk meningkatkan kepatuhan pajak melalui paradigma pelayanan dianggap relevan dan penting dilakukan. Insentif ini semakin bermakna dengan digulirkannya reformasi perpajakan yang mengedepankan komunikasi, interaksi dan pelayanan terhadap wajib pajak. Serupa dengan argumen bahwa paradigma tradisional tidak lengkap, Kirchler et al. (2008) mengemukakan perlunya interaksi antara enforcement effort sebagai bentuk kekuasaan (power) dengan insentif fasilitasi sebagai bentuk kepercayaan (trust) yang kemudian melengkapi 2 paradigma sebelumnya dengan memperkenalkan 
kepercayaan. Dua argumen ini seakan menegaskan bahwa paradigma enforcement saja tidak lagi mangkus untuk meningkatkan kepatuhan pajak. Meskipun terdapat dua paradigma perluasan yaitu paradigma pelayanan dan paradigma kepercayaan, penelitian ini hanya memfokuskan kepada paradigma pelayanan.

Selain itu, reformasi dalam bidang teknologi informasi dengan penggunaan e-SPT dan layanan berbasis tekonologi informasi lainnya juga akan semakin baik jika komunikasi dan informasi serta sosialisasi penggunaannya semakin baik dari fiskus. Bantuan ekstra berupa sosialisasi dan asistensi penggunaan perangkat teknologi informasi ini akan membuat wajib pajak merasa bahwa interaksi mereka dengan fiskus berada dalam arah positif (positive light). Pada gilirannya, perasaan positif ini akan meningkatkan kepatuhan wajib pajak.

McBarnett (2004) seperti dikutip dari Alm et al. (2010) menyatakan bahwa kebijakan penegakan hukum yang bertujuan meningkatkan kepatuhan pajak akan bervariasi berdasarkan kebijakan yang diambil. Kebijakan tersebut akan direspon oleh faktor motivasi wajib pajak. Ada wajib pajak yang merespon dengan patuh dengan sepenuh hati (yang ia sebuat sebagai "committed compliance"), ada yang patuh tidak dengan sepenuh hati (capitulative compliance), ada yang patuh dengan mengambil keuntungan dari regulasi untuk meminimalkan pajaknya (creative compliance) serta terdapat wajib pajak yang merespon dengan ketidakpatuhan (noncompliance). Hampir sama, Braithwaite (2003a) dan Braithwaite (2009) dikutip dari Alm et al. (2010) berargumen bahwa wajib pajak mempunyai motivasi berbeda terhadap upaya-upaya enforcement oleh pemerintah. Mereka dapat dimotivasi oleh motif "deterrence" maupun motif "defiances".

\subsection{Model lainnya}

Murphy (2008) mempertentangkan kedua pendekatan deterrence dan akomodatif dengan mengajukan pertanyaan, apakah sebagainya strategi penegakan hukum pajak sebagai mekanisma hukuman atau mekanisma persuasif. Hasil studinya menunjukkan bahwa pendekatan dengan punitive hanya akan efektif untuk jangka pendek tetapi akan berdampak negatif dalam jangka panjang. Sebaliknya, strategi yang lebih akomodatif yang dipersepsikan lebih adil, lebih hormat dan lebih reintegratif akan dapat menghasilkan kepatuhan sukarela dalam jangka panjang. Simone, Sensing dan Keidman (2013) mengemukakan bahwa strategi terbaik adalah yang menciptakan mutually beneficial, yaitu strategi penciptakan hubungan pajak melalui program kepatuhan yang menghasilkan biaya pemeriksaan rendah bagi fiskus dan biaya kepatuhan yang lebih rendah bagi wajib pajak. Menurut mereka, kedua biaya dapat lebih rendah jika wajib pajak tidak cenderung untuk mengklaim posisi pajaknya dengan dukungan bukti yang lemah dan sebaliknya fiskus tidak cenderung untuk menantang posisi wajib pajak dengan dukungan internal yang kuat dari program yang dilakukan.

Felt dan Frey (2006), meskipun mendasarkan kajiannya utamanya pada model deterrence tradisional, akan tetapi upaya penegakan hukum pajak yang diiringi dengan interaksi yang baik antara wajib pajak dan fiskus akan dapat meningkatkan kejujuran wajib pajak dan mengurangi kecenderungan mereka untuk 
melakukan penggelapan. Dalam studi tersebut juga ditekankan masalah keadilan pajak (variabel dari model psikologi fiskal). Mereka menemukan bahwa, wajib pajak akan tetap melaporkan kewajiban perpajakan mereka dengan jujur meskipun tidak menerima barang dan jasa publik yang dinilai sebanding dengan pajak yang mereka bayar asalkan proses politik berjalan dengan adil dan legitimat. Pada level prosedur, kepatuhan akan meningkat jika wajib pajak mendapatkan perlakuan yang bersahabat dari fiskus. Dalam konteks keadilan secara umum, sudah cukup banyak penelitian yang meneliti pengaruh keadilan (distributif, prosedural dan interaksional) terhadap kepatuhan pajak. Namun, masih belum terdapat penelitian yang menguji pengaruh keadilan tersebut dengan pendekatan multifoci yang membagi keadilan distributif dan prosedural sebagai keadilan organisasional dan keadilan interaksional (informasional dan interpersonal) sebagai bentuk keadilan yang diberikan oleh aparatur pajak sebagai administrator fiskal negara. Lainnya, masih sedikit penelitian yang menghubungkan keadilan dengan masalah kepercayaan wajib pajak dalam studi kepatuhan pajak.

\section{KESIMPULAN}

Pertanyaan mengenai mengapa wajib pajak patuh dan tidak patuh masih menjadi perhatian baik bagi fiskus maupun akademisi. Dari berbagai perspektif yang dikemukan dan teori yang menjelaskan dapat disimpulkan bahwa kepatuhan pajak adalah masalah keperilakuan. Secara garis besar terdapat dua teori yang menjelaskan fenomena ini, yaitu model economic deterrence dan model psikologi fiskal dan sosial. Dari kedua kelompok teori/model tersebut, telah banyak diteliti variabel-variabel yang menjelaskan tentang kepatuhan pajak yang diklasifikasikan menjadi tiga kelompok variabel yaitu moral/etika pajak, keadilan pajak dan ukuranukuran pencegahan. Kemudian, upaya pencarian model atau strategi enforcement pun telah banyak diupayakan dan didokumentasikan dalam berbagai studi. Klasifikasi oleh Alm et al. (2010) barangkali merupakan yang paling umum digunakan. Mereka membagi upaya penegakan kepatuhan pajak ke dalam tiga paradigma yaitu paradigma tradisional deterrence, paradigma pelayanan dan paradigma kepercayaan (trust). Paradigma pertama konsisten dengan penjelasan teori economic-deterrence sementara dua paradigma lainnya diturunkan dari model psikologi sosial dan fiskal..

\section{REFERENCES}

Allingham, M.G dan Agnor Sandmo, 1972. Income Tax Evasion: A Theoretical Analysis. Journal of Public Economics 1 (4): 323338

Alm, James dan Benno Torgler. 2011. Does Ethics Matter? Tax Compliance and Morality. Journal of Business Ethics 101: 635-652.

Alm, James; Betty R. Jackson dan Michael Mckee. 2009. Getting the Word Out: Enforcement Information Dissemination and Compliance Behavior. Journal of Public Economics 93: 392402.

Alm, et al. 2010. Taxpayer Information Assistance Service and Tax Compliance Behavior. Journal of Economic Psychology 31: 577-586 
Alm, James; Betty R. Jackson dan Michael Mckee. 1992. Estimating The Determinant of Taxpayer Compliance with Experimental Data. National Tax Journal, 45: 107-116.

Arisanti, Ana. 2010. Kenapa Kenaikan Tax Ratio Indonesia Lamban? Kini sudah terjawab. Ditulis di www.pelitaonline/read.

Asnawi, Meinarni. 2007. Keputusan Kepatuhan Pajak: Strategi Audit, Tingkat Audit, Perceived Probability of Audit dan Pemahaman Etika Pajak dalam Desain Experimental: Aplikasi dalam Riset Ilmu Ekonomi, Manajemen dan Akuntansi. Yogyakarta: Formadegama, Program Magister Sains dan Doktor IImu-IImu Ekonomi UGM.

Asnawi et al., 2009. Analisis Keputusan Kepatuhan Pajak: Strategi Audit Random, Perceived Probability of Audit dan Pemahaman Etika Perpajakan. Prosiding SNA XII Palembang.

Antonides, G., and H. S. J. Robben. 1995. True positives and false alarms in the detection of tax evasion. Journal of Public Psychology 16 (4): 617-640.

Basri, dkk. 2012. Studi Ketidakpatuhan Pajak: Faktor yang Mempengaruhinya: Kasus pada WPOP yang terdaftar di KPP Tampan, Pekanbaru. Prosiding Simposium Nasional Akuntansi $\mathrm{XV}$ di Banjarmasin.

Becker, G. S. 1968. Crime and Punishment: An Economic
Approach. Journal of Political Economy 76: 169-217

Braithwaite, V. 2003. Dancing with the Tax Authorities: Motivasional Postures and Non-Compliance Action. In Taxing Democracy, Understanding Tax Avoidance and Tax Evasion, Ed V. Braithwaite, 15-39. Adsershot: Ashgate

Collins, Julie $\mathrm{H}$; Valerie $\mathrm{C}$ Milliron dan Daniel R. Toy (2001). Determinants of Tax Compliance. Journal of American Taxation Association 23 (2): 23-39

Cuccia, A. D. 1994. The economics of tax compliance: What do we know and where do we go? Journal of Accounting Literature 13: 81-116.

Devos, Ken. 2014. Factors Influencing Individual Taxpayer Compliance Behavior. London: Springer Science and Business Media.

Fatemi, Hasseldine dan Hite, 2008. Resisting Framing Effect: The Importance of Prior Attitude on Estate Tax Preferences. Journal of American Taxation Association 30 (1): 101-121.

Feltham, Glenn D dan Suzanne M. Paquette. 2002. The Interralationship between Estimated Tax Payment and Taxpayers Compliance. Journal of American Taxation Association 24 (supplement):27-45.

Ghost, Dipanker dan Terry L. Crain. 1996.

Experimental Investigation of Ethical Standards and Perceived Probability of Audit on Intertional 
Noncompliance. Behavioral Research in Accounting 8 (Supplement): 219-244

Graetz, M. J., and L. L. Wilde. 1985. The economics of tax evasion: Fact or fantasy. National Tax Journal 38: 355-363.

Hasseldine, et al. 2007. Persuasive Communications: Tax Compliance Enforcement Strategies for Sole Propritorship. Contemporary Accounting Research, 24(1): 171-194

Jackson, B. R., and V. C. Milliron. 1986. Tax compliance research: Findings, problems and prospects. Journal of Accounting Literature 5: 125161.

Kaplan, Steven E, Kaye J. Newbwerry dan Philip M. J Reckers. 1997. The effect of Moral Reasoning and Educational Communication on Intentional Tax Evasion. Journal of American Taxation Association 19 (2): 38-54.

Kirchler et al. 2008. Enforcement versus Voluntary Tax Compliance: The Slippery Slope Framework. Journal of Economic Psychology 29: 210225

Lewis, A. 1982. The Psychology of Taxation. Oxford, UK: Martin Robinson Publisher

Milliron, V. C dan D. R Toy. 1988. Tax Compliance: An Investigation of Key Features. Journal of The American Taxation Association 6 (2): 19-33
Schepanski dan Kelsey, 1990. Testing for Framing Effect in Taxpayer Compliance Decision. Journal of American Taxation Association 8(2): 21-34

Simone, Lisa D, Richard C. Sansing dan Jeri K. Seidman. 2013. When are Enhanced Relationship Tax Compliance Programs Mutually Beneficial? The Accounting Review 88 (6): 1971-1991.

Schwartz, R dan S Orlenas. 1967. On Legal Sanction: University of Chicago Law Review 34: 282300

Slemrod, J. 2007. Cheating Ourselves: The Economics of Tax Evasion. Journal of Economic Perspectices 21 (1): 25-48

Song, Y. D., and T. T. Yarbrough. 1978. Tax ethics and taxpayer attitudes: A survey. Public Administration Review 38: 442452.

Spicer, M. W., and L. A. Becker. 1980. Fiscal inequity and tax evasion: an experimental approach. National Tax Journal 33:171175.

Srinivasan, T. 1973. Tax evasion: A model. Journal of Public Economics 2:339-346.

Thibaut, J. W., N. Friedland, and L. Walker. 1974. Compliance with rules: Some Social determinants. Journal of Personality and Social Psychology 30 (6): 792-801.

Thurman, Q. C. 1991. Taxpayer noncompliance and general prevention: An expansion of the 
deterrence model. Public Finance 46 (2): 289-298.

Torgler, B. 2003. To evade taxes or not to evade: that is the question. Journal of Socio-Economics 283-302.

Torgler, B. 2004. Moral suasion: An alternative tax policy strategy? Evidence from a controlled field experiment in Switzerland. Economics of Governance 5:235-253.

Trivedi, V. U., M. Shehata, and S. Mestelman. 2005. Attitudes, incentives and tax compliance. Canadian Tax Journal 53 (1): 29-61.

Violette, G, 1989. Effects of Communicating Sanctions on Taxpayer Compliance. Journal of the American Taxation Association 11(1): 92-104,
White, R.. P. Harrison, and A. Harrell. 1993. The impact of income tax withholding on taxpayer compliance: Further empirical evidence. Journal of the American Taxation Association 15 (2): 63-78.

Worsham Jr, Ronald |G. 2006. The Effect of Tax Authority Behavior on Taxpayer Compliance: A Procedural Justice Approach. Journal of American Taxation Association 18(2): 19-39.

Yitzhaki, S. 1974. Income tax evasion: A theoretical analysis. Journal of Public Economics 3:201-202. 